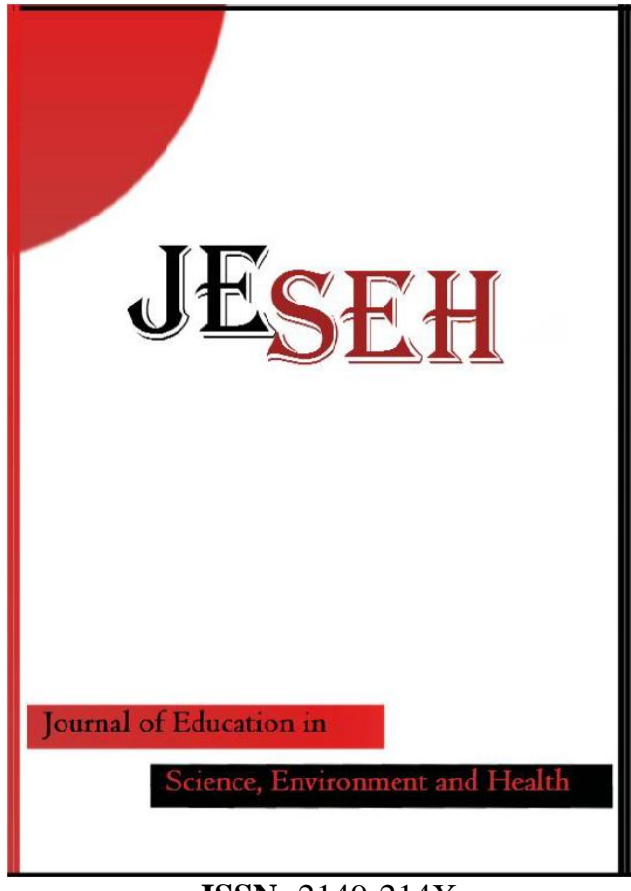

ISSN: $2149-214 \mathrm{X}$

\section{Journal of Education in Science,} Environment and Health

\author{
www.jeseh.net
}

Pre-Service Science Teachers' Learning and Teaching Experiences with Digital Games: KODU Game Lab

\section{Gulsah Uluay ${ }^{1}$, Alev Dogan ${ }^{2}$}

${ }^{1}$ Ordu University

${ }^{2}$ Gazi University

To cite this article:

Uluay, G. \& Dogan, A. (2020). Pre-service science teachers' learning and teaching experiences with digital games: KODU game lab. Journal of Education in Science, Environment and Health (JESEH), 6(2), 105-119. DOI:10.21891/ jeseh.668961

This article may be used for research, teaching, and private study purposes.

Any substantial or systematic reproduction, redistribution, reselling, loan, sub-licensing, systematic supply, or distribution in any form to anyone is expressly forbidden.

Authors alone are responsible for the contents of their articles. The journal owns the copyright of the articles.

The publisher shall not be liable for any loss, actions, claims, proceedings, demand, or costs or damages whatsoever or howsoever caused arising directly or indirectly in connection with or arising out of the use of the research material. 


\title{
Pre-Service Science Teachers' Learning and Teaching Experiences with Digital Games: KODU Game Lab
}

\author{
Gulsah Uluay, Alev Dogan
}

\begin{tabular}{|c|c|}
\hline Arti & Abstract \\
\hline tory & \multirow{9}{*}{$\begin{array}{l}\text { The aim of this paper is to introduce Kodu Game Lab to pre-service science } \\
\text { teachers through a method course based on MAGDAIRE framework and prepare } \\
\text { them to design their own digital games. In accordance with this purpose, key } \\
\text { factors towards using digital games in classroom are also observed. Convergent } \\
\text { parallel design that is a type of mix method research design was used in this } \\
\text { study. This study is performed with a total of } 18 \text { pre-service teachers (PSTs) who } \\
\text { were senior students in a teacher education program of a public university in } \\
\text { Turkey. PSTs voluntarily formed six groups and designed their own digital } \\
\text { games collaboratively based on DGBL-ID Model. Technical Proficiency of } \\
\text { Kodu Skills Test (TPKS-T), rubrics for group and personal assessment and } \\
\text { observation form were used to collect data. According to analyses of data } \\
\text { collected with TPKS-T, post-test mean of PSTs is significantly higher than their } \\
\text { pre-test means. Findings of rubrics showed that PSTs' determined performance } \\
\text { levels are directly proportionate to practices. Also, findings obtained with } \\
\text { observation form are promoted this result. It can be suggested that knowledge } \\
\text { and skills, pedagogical beliefs and culture have an effect on integrating digital } \\
\text { games into learning process. }\end{array}$} \\
\hline Rece & \\
\hline er 2019 & \\
\hline 2019 & \\
\hline Keywords & \\
\hline & \\
\hline & \\
\hline & \\
\hline ation & \\
\hline
\end{tabular}

\section{Introduction}

Since the potential of technology to improve student learning and help change education in 1900s, researchers' interest in this field has increased day by day (Hew and Brush, 2007). In recent years, many researchers have examined the effectiveness of digital technologies in educational processes, and one of the researched topics in this area is the studies based on digital games (Liu and Chen, 2013). In fact, there is an increasing interest about using well-designed digital games that can promote learning in various disciplines (Gee, 2005; Shaffer, Halverson, Squire and Gee, 2005; Shute, Rieber and Van Eck, 2011). Various definitions towards digital games can be seen in related literature. For example, according to Granic, Lobel and Engels (2014), digital games been interactive engage players actively in game world and the world react to players agentive behaviors. Koster (2013) defined digital games as puzzles to solve and brain exercises. Vogel, Vogel, Cannon-Bowers, Bowers, Muse and Wright (2006) determined that digital games are activities had objectives and given feedback. Thus, we can say that digital games are explained with focusing different qualities. Whitton (2010) investigated the qualities of digital games that are suggested in the literature and stated the qualities of digital games that are especially used in learning environments. The researcher suggested that there are ten qualities of these games been presented in Table 1.

When these qualities of digital games are taken into consideration, it can be determined that digital game-based learning is one of the learning methods that can be used for effective learning. According to Bruner (1961), when learning process is active, goal directed, contextualized and interesting, effective learning occurs in the classroom environment. Also, feedback has a positive effect on learning (Ifenthaler, Eseryel and Ge 2012). It is clear that conditions for effective learning have parallels with qualities of digital games.

\section{Theoretical Framework and Literature Review}

Learning is connected with play closely (Amory, Naicker, Vincent and Adams, 1999). Digital games been used for educational purposes are absorbing and immersive implementations to attain specified learning objectives, outcomes and experiences (De Freitas, 2006). Prensky (2001) determined that fun and educational content must be balanced with each other to design an efficient educational game. 
Table 1. Defining qualities of digital games (Whitton, 2010)

\begin{tabular}{|c|c|}
\hline Quality & Definition \\
\hline Competition & $\begin{array}{l}\text { This quality requires winning the game with a higher score than the } \\
\text { other player(s). Also, the player can compete with one's own by } \\
\text { trying to get a higher score than his/her old score. }\end{array}$ \\
\hline Challenge & $\begin{array}{l}\text { This quality requires a task that has an unordinary process to win the } \\
\text { game. Player should make an effort to achieve the outcome. Also, the } \\
\text { task should have various difficulty levels. }\end{array}$ \\
\hline Exploration & $\begin{array}{l}\text { This characteristic is related to a game environment that can be real, } \\
\text { virtual or simulated. The game environment should be discovered by } \\
\text { the player. Discovery of the environment arouses player's curiosity } \\
\text { since game world has different objects and characters. }\end{array}$ \\
\hline Fantasy & $\begin{array}{l}\text { This quality is about creating a fictional game world and game } \\
\text { scenario that describes relationships between the characters and game } \\
\text { environment. }\end{array}$ \\
\hline Goals & $\begin{array}{l}\text { Digital game should have clear purposes and objectives. Goals } \\
\text { present explanations about actions to be taken to win or complete the } \\
\text { game. Also, players are informed about goals what the game want } \\
\text { and why they are playing the game. }\end{array}$ \\
\hline Interaction & $\begin{array}{l}\text { Players can influence the game situation by stepping into action and } \\
\text { thus the game changes and gives directions/feedback to the players } \\
\text { about deciding their next actions. }\end{array}$ \\
\hline Outcomes & $\begin{array}{l}\text { This quality is a mechanism that presents feedback which a goal is } \\
\text { achieved, how far a player is accomplishing the goal or how far a } \\
\text { player is close to achieving the goal in contrast with the other players. } \\
\text { For example, scoring can be used for measurable outcomes. }\end{array}$ \\
\hline People & $\begin{array}{l}\text { This quality is about the players who join the game play. Players } \\
\text { competitively play against each other in most of the games. Also, } \\
\text { they can play collaboratively to achieve group goals. }\end{array}$ \\
\hline Rules & Rules present instructions about playing game and constraints. \\
\hline Safety & $\begin{array}{l}\text { Outcomes of the game have no results such as penalties or rewards in } \\
\text { the real world. }\end{array}$ \\
\hline
\end{tabular}

All qualities of designing digital games that are mentioned above such as challenge, exploration, outcomes (feedback) are in compliance with existed learning theories such as constructivism and flow theory (Qian and Clark, 2016). Prensky (2001) determined that presented challenging in flow state matches with almost perfectly individuals' solving skills of the challenging and individuals can gladly achieve most things been described as unachievable by them. In this regard, learners in a flow state are absorbed in activities and move away from irrelevant opinions and perceptions through a well-designed digital game (Chen, Wigand and Nilan, 1999).

Based on the qualities, it is important to emphasize advantages of digital games for learning environments. Digital games are user-centered activities (Gros 2007) and these activities give an opportunity about learning through experience to students (Baek 2010; De Freitas 2006; Kirriemuir 2002). In this context, digital games promote and increase learning (Natale 2002) and improve students' self-efficacy (Sitzmann 2011) and selfesteem (Ritchie and Dodge 1992). Also, these games establish learning environments that provide learning with fun (Prensky 2001), learning by discovery (Baek 2010) and cooperative learning (Gros 2007). In addition to these, digital games increase students' attendance to course (Gros 2007; Spires 2015) and provide immediate feedback to learners (Ifenthaler et al. 2012; Whitton 2010). Besides, digital games develop learners' skills such as problem solving (Akcaoglu 2013, Akcaoglu and Koehler 2014; Gros 2007; Spires 2015), decision-making (De Aguilera and Mendiz 2003; Spires 2015), spatial thinking (Feng, Spence and Pratt 2007; Uttal Meadow, Tipton, Hand, Alden, Warren and Newcombe 2013) and computer literacy (Natale 2002). Another important advantage of digital games is increasing learner's motivation (Alaswad and Nadolny 2015; Garris, Ahlers and Driskell 2002; Gee 2005; Mitchell and Savill-Smith 2004; Prensky 2001; Ray and Coulter 2010; Spires 2015).

When qualities and advantages of digital games are taken into consideration, it can be stated that digital games are seen as an important approach for science education since these games enable students to see representations of natural phenomena and interact with these phenomena, and promote students' developments towards explaining these phenomena scientifically (National Research Council 2011). Strengths of digital games in science field indicated as providing opportunities to students about observing, exploring, managing variables, and providing immediate feedback since these opportunities involve situations such as time-consuming, 
expensive or dangerous experiences in a traditional science course (Winn 2002). In this respect, pre-service science teachers were preferred for this study.

\section{Purpose}

The main purpose of this paper is to introduce Kodu Game Lab to pre-service science teachers through a method course based on MAGDAIRE framework and prepare them for designing their own digital games. After PSTs completed implementations of MAGDAIRE framework, they conducted their own digital game activities in real classrooms by means of traineeship process. In accordance with this purpose, this paper grounds on the following research questions:

(1) What are the effects of implementation process to developments of pre-service science teachers' skills towards using digital game-based learning to teach a particular topic?

(2) What are the effects of implementation process and traineeship process on PSTs' performance levels about usage of digital games in classroom?

\section{Method}

In this study, we used mixed method research design. In contrast with any method, using both qualitative and quantitative methods offer opportunity about developing a better understanding with respect to research problems and questions (Creswell, 2012). Convergent parallel design was used in this study. The purpose of this research design is to collect qualitative and quantitative data simultaneously, combine the data, and use results to comprehend determined research problem (Creswell, 2012). In this type of mixed method research design, researcher collects both qualitative and quantitative data, analyses both group of data independently, contrasts the findings and results obtained from the analysis, and makes comments about whether the results support or conflict with each other or not.

\section{Participants}

In this study, all participants were senior students in a teacher education program of a public university in Turkey. They were a total of 18 PSTs who took a course termed as special teaching methods and traineeship. 10 of all participants were female and 8 of them were male.

\section{Procedures}

In Turkey, the higher education system is supervised by the Council of Higher Education (CoHE) and the CoHE is responsible for designing, coordination and governance of higher education system. According to CoHE's system, the senior students who are in department of science education professional teaching knowledge courses such as educational psychology, teaching principles and methods, and instructional technologies and material design; general culture courses such as scientific research methods, and computer lessons; and complete major area courses such as environmental science (CoHE, 2016). It is aimed to make pre-service teachers recognize teaching methods and materials and prepare their own lesson plans and practice them with professional teaching knowledge courses. In this study, we termed this process as implementations of MAGDAIRE. Also, pre-service teachers experience teaching in real classroom environments with traineeship process. According to content of the course, pre-service teachers do traineeship in public middle schools during spring term. In our study, this process was started after MAGDAIRE implementations and was termed as traineeship process. In parallel with the curriculum of institutions for teacher training, subject matters about biological environment termed as people-environment relations and living creatures and energy relations take part in curricula of middle-school education.

In this paper, a science course subject of 7 th grade of secondary school that is termed as "People-Environment Relations" was chosen to create lesson plan. Six main topics of mentioned course subject were determined as follows: (1) Explaining relations of living organisms between each other and lifeless organisms, (2) living diversity and climatic characteristics of ecosystems, (3) biological diversity and its importance, (4) indicating endangered species and offering suggestions protecting facilities for the species, (5) explaining environmental issues and their effects on environment, and (6) nutrition relationship in ecosystem. 
In this study, we used Digital Game Based Learning-Instructional Design Model (DGBL-ID) that was designed by Zin, Yue and Jaafar (2009) and DGBL-ID was adapted for science teaching. DGBL-ID consists of five phases as analysis, design, development, quality assurance and implementation and evaluation as illustrated in Fig. 1. In analysis phase, problems that students face throughout learning course subject are determined and student readiness for DGBL is investigated. Also, digital game platform such as computer, smart phone and qualities of digital game are identified in this phase. Method and teaching strategies that will be used in instructional digital game are explained in design phase. Technical characteristics of digital game, characters, objects, game environment and game feedback are described, and features of characters and their movements are determined. Besides, course plan that will be integrated into digital game and kinds of teaching sources are stated. Digital game levels that involve some phases such as challenging, traps are designed in this phase. Type of game technology is clarified, and data pertained to user and scores of the user should be recorded at data source of prototype in development phase. Developed prototype is tested in the phase of quality assurance. By this means, first version of the digital game's quality can be controlled before implementation. In the last phase termed as implementation and evaluation, prototype that was completed the processes of testing and developing was installed into computers that will be used by the students and the prototype is used in the learning environments.

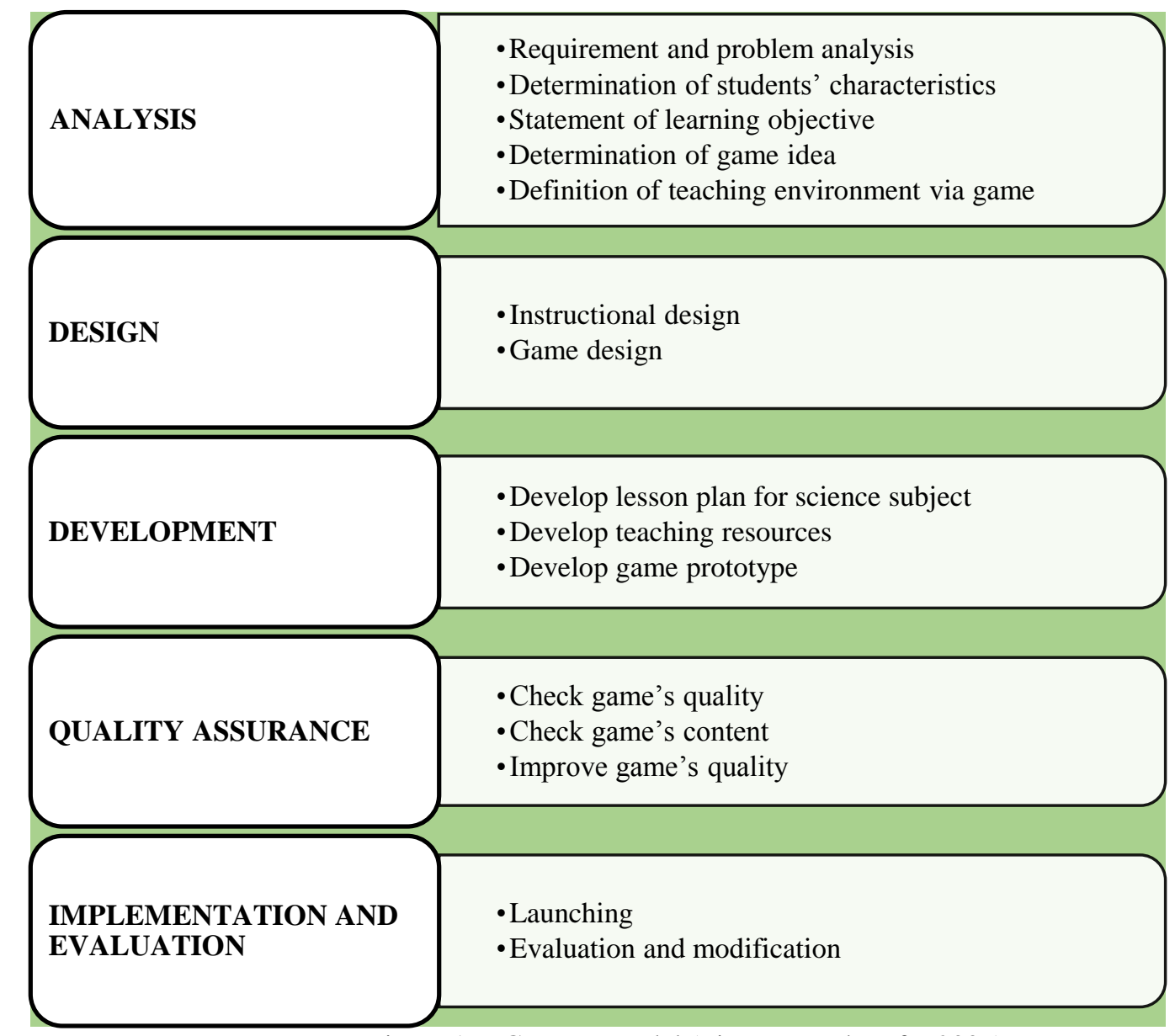

Figure 1. DGBL-ID model (Zin, Yue and Jaafar 2009)

We used Microsoft Kodu Game Lab to design digital games. Kodu is a visual programming that makes more specific creating a game (http://research.microsoft.com/en-us/projects/kodu/). Kodu is designed specifically for young children to learn through independent exploration (MacLaurin, 2011). Kodu has a simple language and entirely icon-based (http://www.kodugamelab.com/resources/). Kodu rules are regular expressions with a simple syntax (Touretzky, 2014). The software is integrated in a 3D game environment and it presents more appealing visual for students (Akçaoğlu, 2013). In addition to these, Kodu for the PC is free to download. Due to Kodu's accessibility, easier to use and visual appeal, as mentioned previously, we choose this software, because teachers are in need of reaching resources quite easily (Becker 2007). 


\section{Implementation Process}

The present study's course plan was performed based on MAGDAIRE framework (Chien, Chang, Yeh and Chang, 2012). The framework consists of four phases termed as modeled analysis, guided development, articulated implementation, and reflected evaluation and the phases are respectively followed for one cycle. When first cycle is completed, it is returned to first phase (modeled analysis) and the cycle is repeated. Implementation process lasted a total of 12 weeks. Schedule of the implementation process is presented as follows:

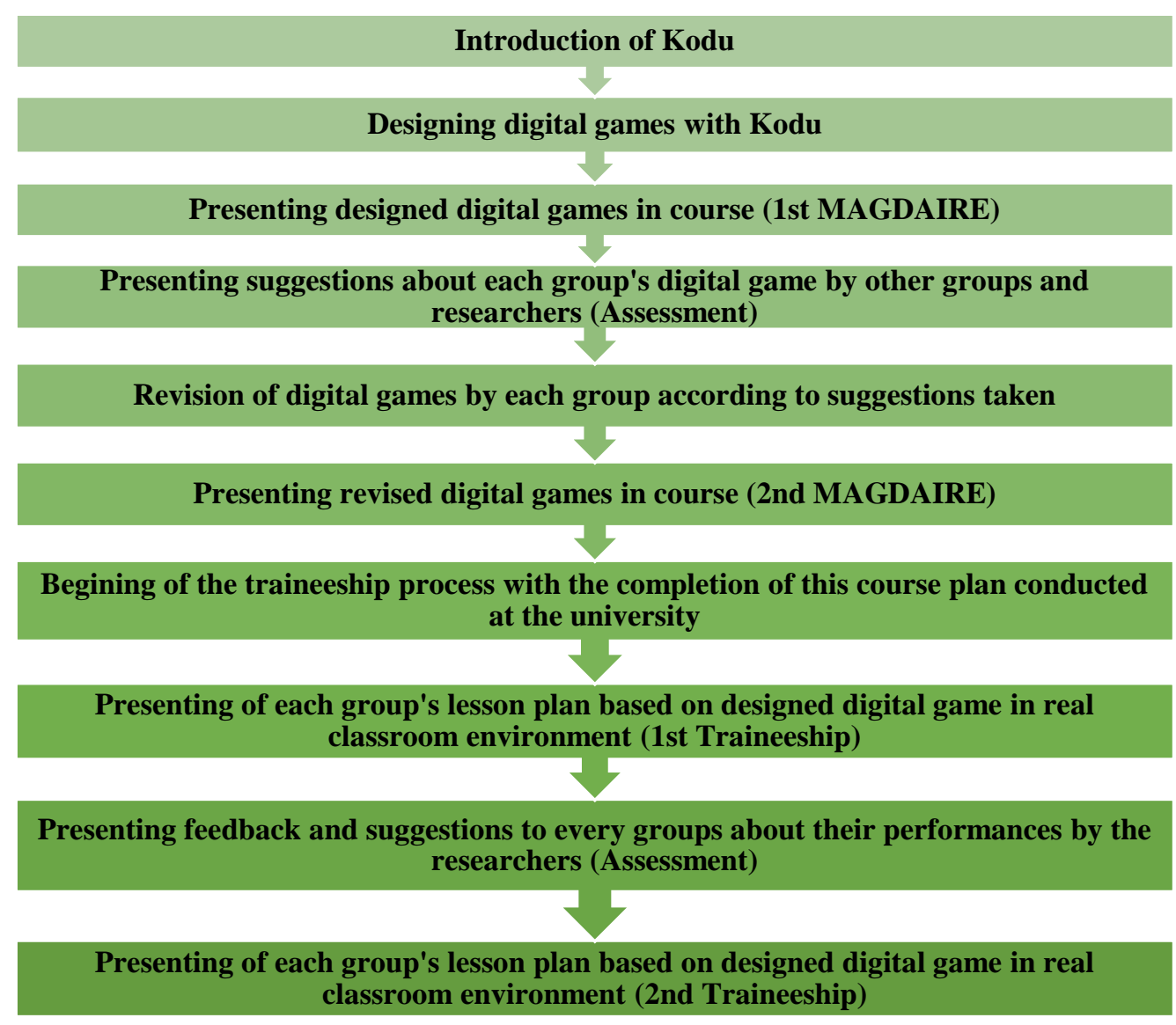

Figure 2. Schedule of the implementation process

18 of PSTs who participated in this course voluntarily formed six groups. In the process beginning, we introduce Kodu to PSTs respectively with the topics as follows: (1) Introduction about encountered first windows in start-up screen, (2) tools and objectives; and usage information about them, (3) painting, adding, or deleting ground, (4) adding or editing characters or objects, (5) programming, (6) adding or editing paths, (7) adding, removing, or tinting water, (8) scoring and winning the game, (9) adding a countdown or enumerative timer, (10) introduction about world settings tabs and objectives, and (11) creating a new world as an example. During the introduction process, we firstly presented the characteristics of mentioned phases and implemented all of them. As soon as we completed presentation of a phase, PSTs performed the same phase with their own laptops. By this means, they found opportunity about learning by doing and also, we could comprehend whether or not PSTs understand the use of any phase and were keeping up.

After the presentation process of Kodu was completed, each group started to create their own digital games that are associated with their own course subjects based on DGBL-ID Model. When they designed their digital games, implementations of the 1st MAGDAIRE cycle were performed. During MAGDAIRE implementations, instructor watched the PSTs' performances and didn't interfere in the course. Instructor took notes about presentations and after completing the MAGDAIRE phase, instructor used the notes to inform PSTs and made them notice their own mistakes. We also organized sessions to give feedback to each group about their activities. Also, PSTs were encouraged to evaluate other groups' activities. By this means, each group offered suggestions to other groups and at the end of the sessions PSTs and researchers introduced solution offers about diverse problems observed from each group's presentation. All groups improved their instructional plans and 
digital games in line with feedback gained. Similar with the 1st MAGDAIRE cycle, each group presented their enhanced digital game activities during the 2nd MAGDAIRE cycle. When the process was completed, we organized sessions again and groups were evaluated for the last time before traineeship process. Implementations of the 1st traineeship process and the 2 nd traineeship process were performed in analogy to MAGDAIRE processes.

A digital game activity is introduced as an example. Goal of the activity is presenting environmental issues and their effects on environment. In accordance with this goal, Kodu will try to save his own world. Game content is presented below:

\begin{tabular}{|c|c|c|}
\hline Rules & Assets & Scoring \\
\hline $\begin{array}{l}\text { - Kodu moves with arrow } \\
\text { keys. } \\
\text { - Kodu collects waste } \\
\text { when he crashes into } \\
\text { them. } \\
\text { - Sputnik represents waste. } \\
\text { - Heart represents air } \\
\text { pollution filter. } \\
\text { - Kodu launches Heart } \\
\text { when S on keyboard is } \\
\text { keystroked. }\end{array}$ & $\begin{array}{l}\text { - Kodu } \\
\text { - Sputnik } \\
\text { - Fish } \\
\text { - Turtle } \\
\text { - Factory } \\
\text { - Tree }\end{array}$ & $\begin{array}{l}\text { - If Kodu collects Sputnik, } \\
\text { he will gain } 5 \text { points. } \\
\text { - If Sputnik crashes into } \\
\text { fish and turtle, they will } \\
\text { hit. } \\
\text { - If Kodu can't collect } \\
\text { Sputnik, trees will hit. } \\
\text { - If Kodu can't attach } \\
\text { filters to flues of } \\
\text { factories,air pollution } \\
\text { will occur. }\end{array}$ \\
\hline
\end{tabular}

Figure 3. Game content

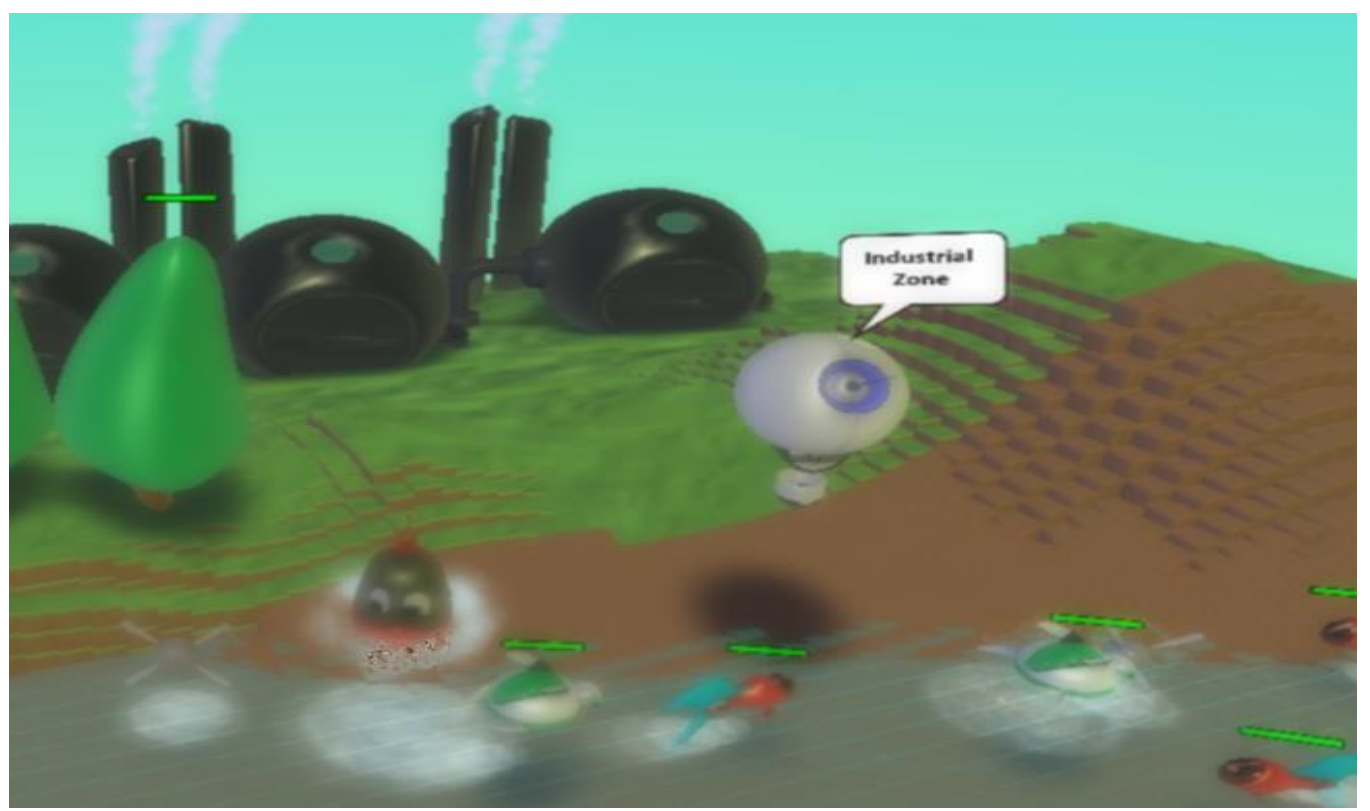

Figure 4. Screenshot from the game

\section{Data Collection}

\section{Technical Proficiency of Kodu Skills Test}

Technical Proficiency of Kodu Skills Test (TPKS-T) was developed as a practical assessment and evaluation instrument. Reliability studies of TPKS-T were performed with 35 PSTs (16 females, 19 males) who study department of Computer and Instructional Technologies. All of PSTs are seniors with an age average of 22.4, ranging from 22 to 23. IBM SPSS Statistics 20.0 software was used for data analysis. Cronbach's alpha value was found as .801 . 
Table 2. Content of TPKS-T

\begin{tabular}{llc}
\hline & \multicolumn{1}{c}{ Implementation } & Score \\
\hline 1 & Creating an island and a lake; create hills and valleys & 5 \\
2 & Adding characters/objects, adjusting their settings & 5 \\
3 & Coding a character & 5 \\
4 & Adding paths, moving on paths & 5 \\
5 & Scoring with effects & 5 \\
6 & Adding timers & 5 \\
7 & Creating a game world by adjusting settings for water, sky and ground & 5 \\
\hline
\end{tabular}

\section{Rubric and Observation}

Rubric is an instruction for scoring to evaluate students' works (Montgomery 2000) and consists of criteria that are stated to measure students' levels of performances (Coffin 2002). A well-designed rubric can help both researchers and students to identify criterion for a successful process and/or product from beginning to end of a task, and also when a similar task is repeated in the future, it provide feedback that is specific to every student for achieving (Montgomery 2002). In this paper, we used two analytical rubrics that include criteria that are divided into different levels of performances (Luft 1999). Since every part of a performance or a product can be evaluated separately with an analytical rubric (Mertler 2001), we chose this type of rubric. By this means, we took the opportunity about evaluating severally all parts of process involved designing and presenting digital games by PSTs. In this context, one of the rubrics termed as "Rubric for Group Oral Presentation" was used to assess group works and second rubric termed as "Rubric for Student Exercise" was used for evaluating PSTs individualistically and both of the rubrics were developed by Montgomery (2002). Since the rubrics were in English, firstly they were translated into Turkish by three experts. Acquired three translations were evaluated by the researchers and two experts whose specialties are computer and instructional technologies. After completing the assessments, Turkish forms were organized by considering suggestions. Coordinated forms were examined by two experts whose specialties are Turkish philology and in the light of their suggestions final versions of the forms were prepared. In this study, we used an observation form that is adapted from Mento and GiampetroMeyer (2000)'s research to follow group presentations and promote data sets of rubrics. The observation form has ten topics named as class beginning; student response; student participation; material (Kodu activities); pacing of material presentation/discussion; sense of the class; student involvement; pedagogical approaches; recurring student assignments; and sense of closure at end of class.

\section{Results and Discussion}

In this study, SPSS software was used to analyze quantitative data. Firstly, data acquired with TPKS-T was analyzed and independent samples t-test was used for the analysis. The effect sizes for t-test were determined and interpreted as Cohen (1988) stated (Cohen's d). Cohen's d is interpreted in the manner of following characterization: $d=.20$ is described as a small effect size, $d=.50$ as a medium effect size and $d=.80$ as a large effect size (Cohen 1988). Analysis results of t-test are illustrated in Table 3.

Table 3. Comparisons of pre-test and post-test scores of TPKS-T

\begin{tabular}{lcccccc}
\hline Group & $\mathrm{N}$ & $\bar{X}$ & $\mathrm{~s}$ & $\mathrm{SD}$ & $\mathrm{t}$ & $\mathrm{p}$ \\
\hline Pre-test mean & 18 & 16.66 & 2.42 & 17 & 5.58 & $.000^{*}$ \\
Post-test mean & 18 & 19.55 & 2.03 & & & \\
\hline *p<.01 & & & & & &
\end{tabular}

The results of independent samples t-test analysis deduce that PSTs' post-test mean $(\overline{\mathrm{x}}=19.55)$ is higher than PSTs' pre-test mean $(\overline{\mathrm{x}}=16.66)$ and there is statistically significant difference between means of pre-test and post-test $\left(\mathrm{t}_{(17)}=5.58, \mathrm{p}<.01\right)$. Effect size for this analysis was calculated as $\mathrm{d}=1.86$ that is evaluated as large effect size. Based on these findings, we can state that it is possible to improve PSTs' Kodu Game Lab skills about designing digital game activities with implementations of MAGDAIRE. After findings of TPKS-T were obtained, we investigated rubrics and observation forms. Firstly, rubrics for group oral presentations were examined and results of the rubric scores for each group (G1, G2, G3, G4, G5 and G6) are demonstrated in following figures. 


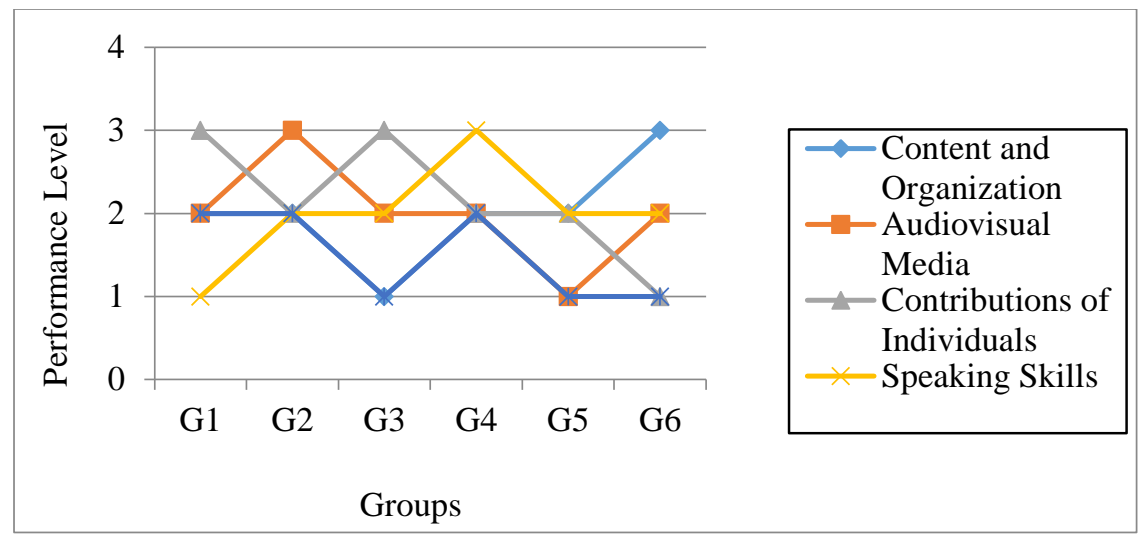

Figure 5. 1st MAGDAIRE cycle

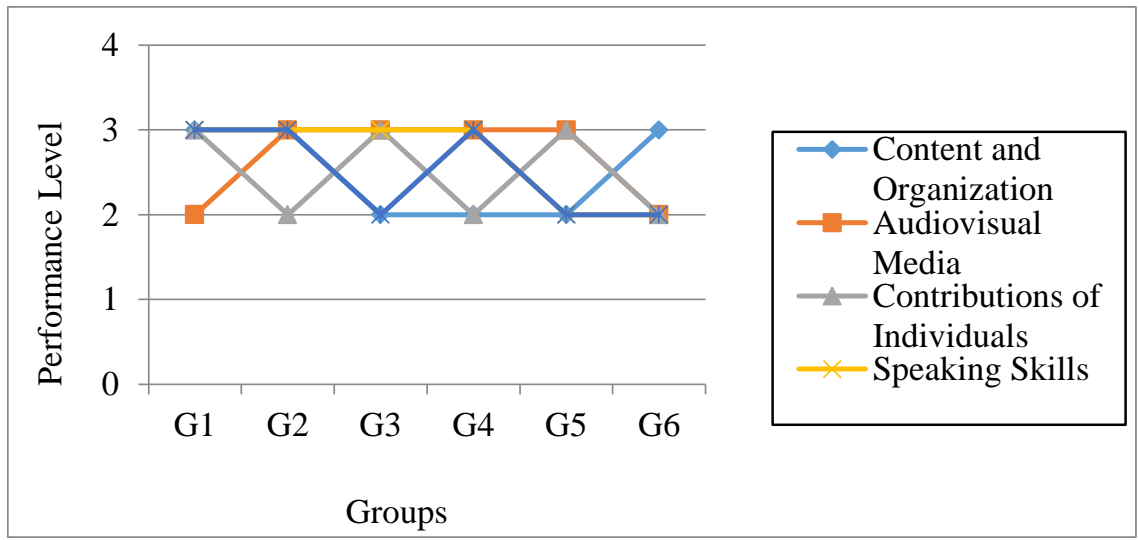

Figure 6. 2nd MAGDAIRE cycle

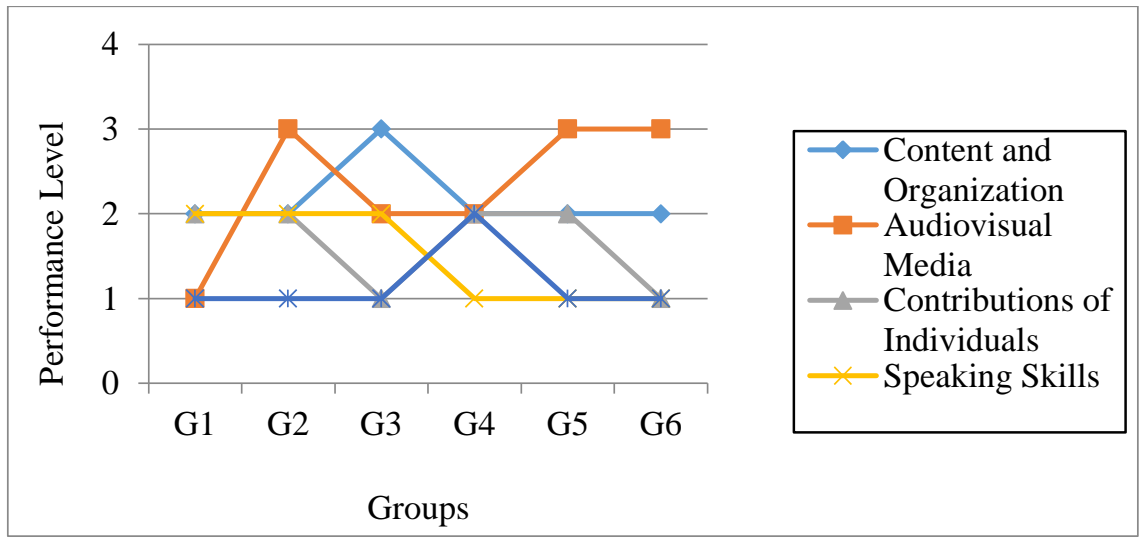

Figure 7. 1st traineeship process

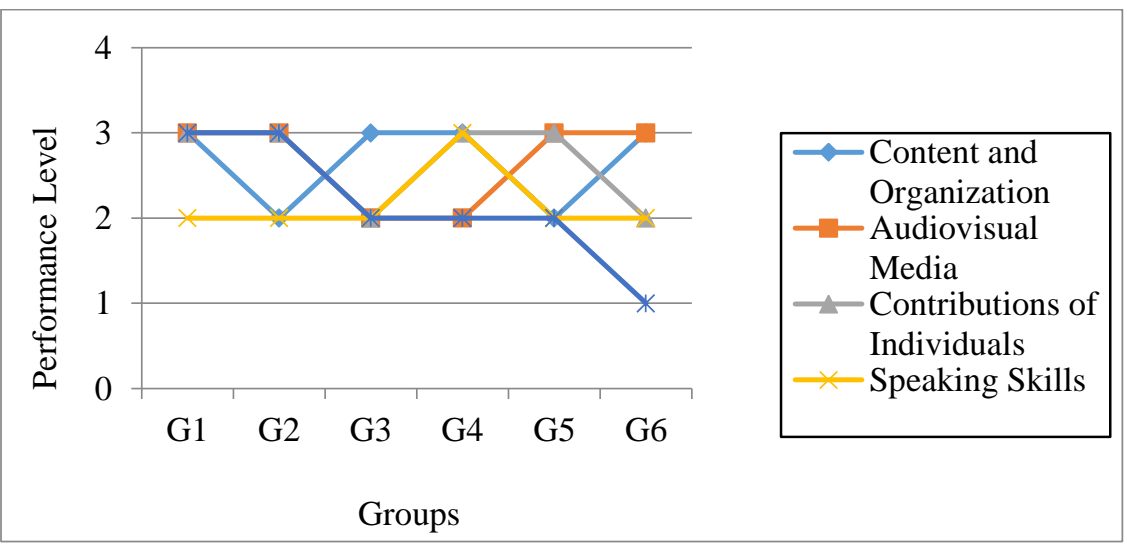

Figure 8. 2nd traineeship process 
As illustrated in figures, it is seen that groups' rubric scores of the 2nd MAGDAIRE cycle performances are higher than their 1st MAGDAIRE cycle scores of performances assessment. After implementations of the 1st MAGDAIRE cycle were completed, the groups implemented their course plans during traineeship process. By the end of the processes, it is conspicuously noticed that groups' rubric scores were decreased again with the 1st traineeship process. When groups practiced their course plans for the second time, it was seen that their rubric scores increased and the 2nd traineeship process scores of performances assessment were higher than rubric scores of the 1st traineeship process. In this context, Wilcoxon Signed Rank Test was used to investigate whether there is a statistically significant difference between acquired rubric scores or not. Analysis results included scores of rubrics for group oral presentations about implementations of MAGDAIRE cycle and traineeship process are shown in Table 4.

Table 4. Analysis results of Wilcoxon Signed Rank Test

\begin{tabular}{|c|c|c|c|c|c|c|}
\hline $\begin{array}{c}\text { Implementation } \\
\text { Pairs }\end{array}$ & & $\mathrm{N}$ & $\begin{array}{l}\text { Mean } \\
\text { Rank }\end{array}$ & $\begin{array}{l}\text { Sum of } \\
\text { Ranks }\end{array}$ & $\mathrm{Z}$ & $\mathrm{p}$ \\
\hline \multirow{3}{*}{$\begin{array}{l}1^{\text {st }} \text { MAGDAIRE } \\
2^{\text {nd }} \text { MAGDAIRE }\end{array}$} & Negative Ranks & 0 & .00 & .00 & $2.232^{*}$ & $.026^{* * * *}$ \\
\hline & Positive Ranks & 6 & 3.50 & 21.00 & & \\
\hline & Ties & 0 & & & & \\
\hline \multirow{3}{*}{$\begin{array}{l}2^{\text {nd }} \text { MAGDAIRE } \\
1^{\text {st }} \text { Traineeship }\end{array}$} & Negative Ranks & 6 & 3.50 & 21.00 & $2.232^{* *}$ & $.026^{* * * *}$ \\
\hline & Positive Ranks & 0 & .00 & .00 & & \\
\hline & Ties & 0 & & & & \\
\hline \multirow{3}{*}{$\begin{array}{l}1^{\text {st }} \text { Traineeship } \\
2^{\text {nd }} \text { Traineeship }\end{array}$} & Negative Ranks & 0 & .00 & .00 & $2.226^{*}$ & $.026^{* * * *}$ \\
\hline & Positive Ranks & 6 & 3.50 & 21.00 & & \\
\hline & Ties & 0 & & & & \\
\hline
\end{tabular}

Differences between each implementation pair are statistically significant since all of significance levels are less than .05 ( $\mathrm{p}<.05)$. When mean rank and sum of ranks are taken in consideration, it is seen that the differences argue for positive ranks. In other words, scores of differences are in favors of implementations of the 2 nd MAGDAIRE and the 2nd Traineeship Process. According to these results, it can be stated that the practices substantially have an impact on promoting PSTs' skills about developing course plans based on DGBL and presenting the plans.

To develop a more detailed point of view about analysis results of rubrics, we examined observation forms. According to our observations, PSTs seemed anxious, excited or unconfident while they were presenting their activities during their 1st MAGDAIRE experiences. Since they couldn't arrange the time, they exceeded the time limit and had to finish their presentations without coming to the end of their course plans. For example, PSTs who are in group 3 didn't greet students and didn't inform them on activities. Since Group 3 didn't invite students to join in the class discussion, students were passive during the process. Activity presentation was too fast, and students didn't have enough time to follow digital game activity being presented. At end of the class, the group had no time for reaching conclusions and providing summary handouts.

While implementations of the 2nd MAGDAIRE were performing, PSTs were sure of themselves compared to their first practices. When we examined performance of Group 3 again, they appeared to feel comforted. In class beginning, they greeted students and gave brief knowledge about the activity. They used the course time well and process of advertising activity was just about right. They encouraged participation of students in groups and encouraged them to class discussions. By this means, students were active during the implementation. Also, assignments of Group 3 seemed to prepare students for the activity. At end of the class, they reached the conclusions and provide summary handouts.

When groups' performances of traineeship process were observed, it was clear that PSTs were excited, stressful or diffident during the 1st Traineeship Process. Because of specified feelings, most of them had problems about classroom management and using the course time. For example, PSTs been in Group 1 created a very serious classroom environment. Students were too quiet and couldn't be part of the course. Group 1 completed the course too soon and they had to retell certain subjects. Contrary to this, Group 4 couldn't present the whole activity since they didn't make use of the time well. Although Group 5 was better than the other groups in the processes of presentation and organization, they had difficulties in communicating with students. Since they mostly mumped between each other, they lost control of the class.

PSTs were more relaxed and controlled during the implementations of the 2nd Traineeship Process. Also, it was seen that performances about group collaboration made progress and each PST was equally involved in the process contrary to the 1 st Traineeship Process. Most of the groups provided a classroom environment for 
students' active participations. They made students work in groups and prepare cases in advance. For example, Group 2 that was the highest scoring group involved the students in their presentation and held their attention from beginning to end. By this means, they didn't encounter any classroom management problem. They had a good grasp of whether or not the students understand the activity and follow the phases. Also, they encouraged students to classroom discussion and listened students' opinions. At end of the class, they had enough time to make assignments and answer students' questions.

To support and detail the data obtained from rubric for group oral presentations, all PSTs' performances evaluated individually from the point of working within group by using "Rubric for Student Exercise". The data obtained from this rubric shows similarity with date set of rubrics for group oral presentations. Such in group performances, PSTs' performance levels of the 2nd MAGDAIRE are higher than rubric scores of the 1st MAGDAIRE.

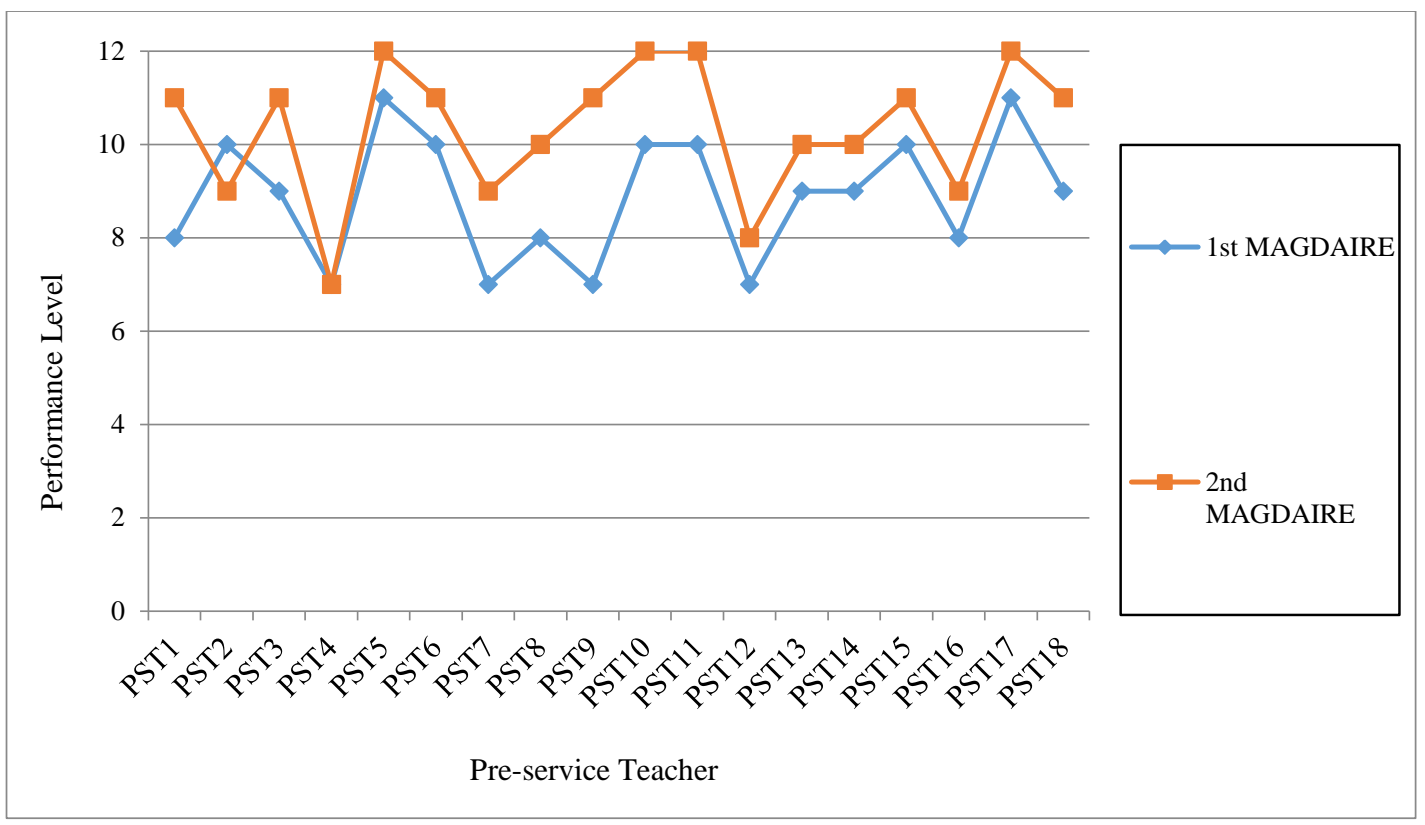

Figure 9. Rubric scores of the 1st MAGDAIRE and the 2nd MAGDAIRE

Each PST's scores are shown in Figure 9 and analysis results of Wilcoxon Signed Rank Test are presented in Table 5. Analysis results showed that statistically significant difference was found between PSTs' rubric scores of the 1st MAGDAIRE and the 2nd MAGDAIRE performances $(\mathrm{z}=3.46, \mathrm{p}<.05)$. According to difference scores of mean rank and sum of ranks, the differences argue for positive ranks. It means that the difference is for the benefit of the 2nd MAGDAIRE practices. In line with these results, designed course plan based on MAGDAIRE framework can be an important factor in developing PSTs' skills about use of digital games in classroom.

Table 5. Analysis results of Wilcoxon Signed Rank Test towards scores of the 1st MAGDAIRE and the 2nd

\begin{tabular}{llccccc}
\multicolumn{7}{c}{ MAGDAIRE } \\
\hline $\begin{array}{c}\text { Implementation } \\
\text { Pairs }\end{array}$ & & $\mathrm{N}$ & $\begin{array}{c}\text { Mean } \\
\text { Rank }\end{array}$ & $\begin{array}{c}\text { Sum of } \\
\text { Ranks }\end{array}$ & $\mathrm{Z}$ & $\mathrm{p}$ \\
\hline \multirow{2}{*}{ 1st MAGDAIRE } & Negative Ranks & 1 & 5.00 & 5.00 & $3.461^{*}$ & $.001^{* *}$ \\
2nd MAGDAIRE & Positive Ranks & 16 & 9.25 & 148.00 & & \\
& Ties & 1 & & & & \\
*Based on negative ranks & $* * \mathrm{p}<.05$ & & & & &
\end{tabular}

According to observations of PSTs' personal experiences, we can determine that most of PSTs controlled their teaching processes in a professional way during the 2nd MAGDAIRE. PST 10 was one of the participants who scored full marks and revealed excellent performance towards system analysis and scientific literacy during the 2nd MAGDAIRE implementation. PST 10 took charge of his own behavior in the group during both 1st MAGDAIRE and the 2nd MAGDAIRE. PST 9 who showed the highest increase in gained total point of Rubric for Student Exercise made progress about working collaboratively with group friends and taking on various roles. 
PST 4 whose rubric point of the 1st MAGDAIRE performance was equivalent to the point of the 2nd MAGDAIRE performance had problems on relating how Kodu system interacts with the curriculum. Total rubric point of PST 2 showed decrease in 2nd MAGDAIRE. Although he revealed excellent performance as a collaborative worker, he couldn't provide personal insight into the interaction of Kodu systems and couldn't offer an alternative option for received criticism.

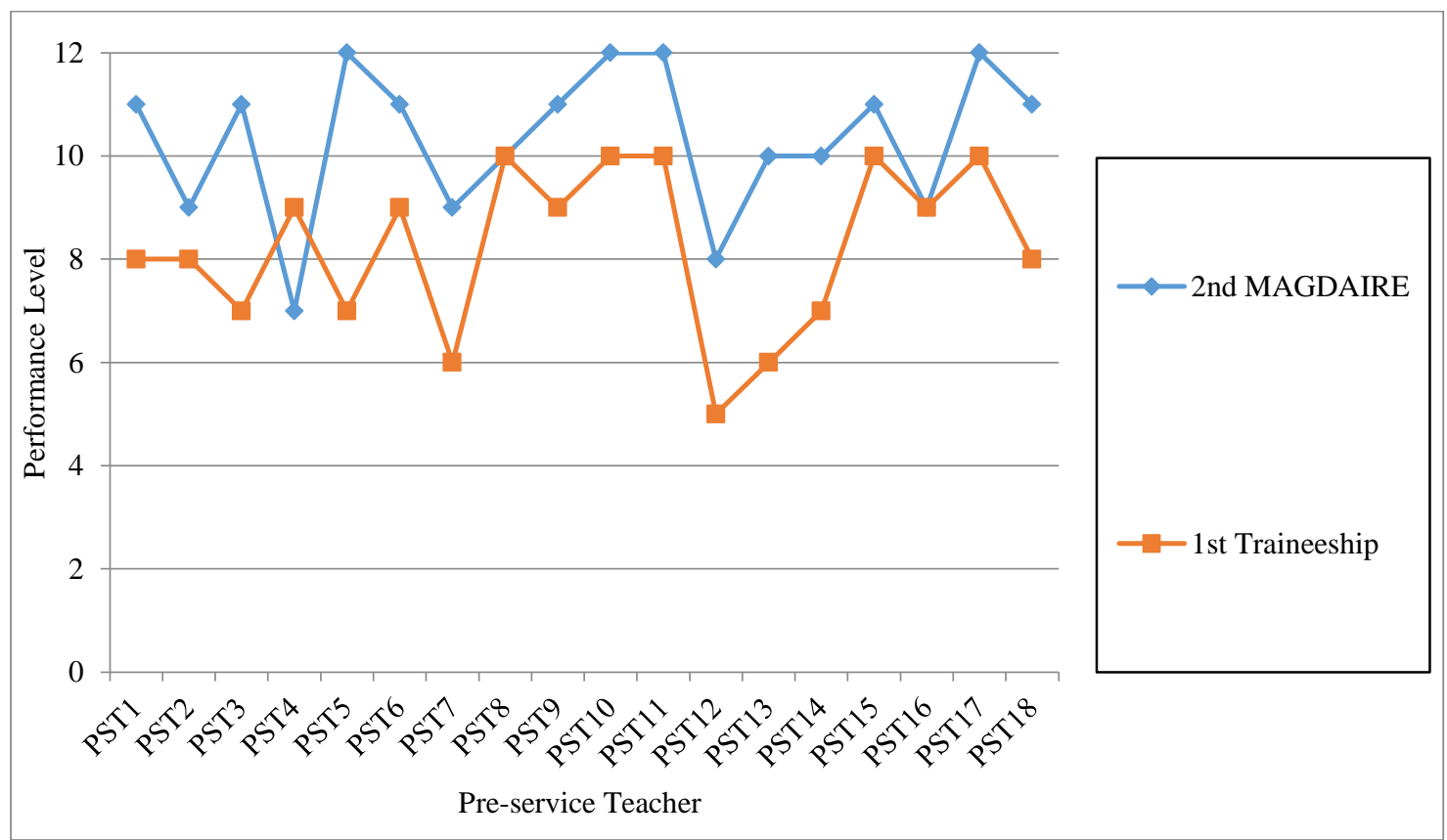

Figure 10. Rubric scores of the 2nd MAGDAIRE and the 1st traineeship process

As is the case with examination of group performances, PSTs' rubric scores decreased in practices of the 1st traineeship process. Each PST's scores are shown in Figure 10 and analysis results of Wilcoxon Signed Rank Test are presented in Table 6. When the rubric scores of the 2nd MAGDAIRE and the 1st Traineeship Process are compared with each other, it is seen that PSTs' scores been acquired from Rubric For Student Exercise of the 1st Traineeship Process are less than scores of the 2nd MAGDAIRE implementations with a statistically significant difference $(z=3.26, p<.05)$. It can be determined that the difference is in favor of negative ranks within the scope of mean rank and sum of ranks. Briefly, analysis results showed that the difference is against the 1st Traineeship Process.

Table 6. Analysis results of Wilcoxon Signed Rank Test towards scores of the 2nd MAGDAIRE and the 1st traineeship process

\begin{tabular}{llccccc}
\hline $\begin{array}{c}\text { Implementation } \\
\text { Pairs }\end{array}$ & & $\mathrm{N}$ & $\begin{array}{c}\text { Mean } \\
\text { Rank }\end{array}$ & $\begin{array}{c}\text { Sum of } \\
\text { Ranks }\end{array}$ & $\mathrm{Z}$ & $\mathrm{p}$ \\
\hline \multirow{2}{*}{ 2nd MAGDAIRE } & Negative Ranks & 15 & 8.70 & 130.50 & $3.263^{*}$ & $.001^{* *}$ \\
1st Traineeship & Positive Ranks & 1 & 5.50 & 5.50 & & \\
& Ties & 2 & & & & \\
* Based on positive ranks & ${ }^{* * \mathrm{p}<.05}$ & & & &
\end{tabular}

One of all PSTs' rubric score showed an increase. 15 of PSTs' rubric scores decreased and two of them remained unchanged. We investigated the data acquired from observation forms to explain reasons of the declines in the rubric scores. For example, PST 5 who was on the most decline didn't respond to the group and couldn't be part of the group. She followed a course plan been organized during her presentation and stuck to the plan. She didn't stray from the plan even if students asked questions to her. Instead of answering the questions, she merely gave directions been determined in the plan without showing flexibility in the limitations of the plan. PST 3 encountered classroom management problems since he behaved sympathetically students too much. Also, each member wasn't equally involved in the presentation in his group and for this reason PST 3 dominated the presentation. Since he lost control of the class, working collaboratively in groups and class discussion couldn't be conducted. 


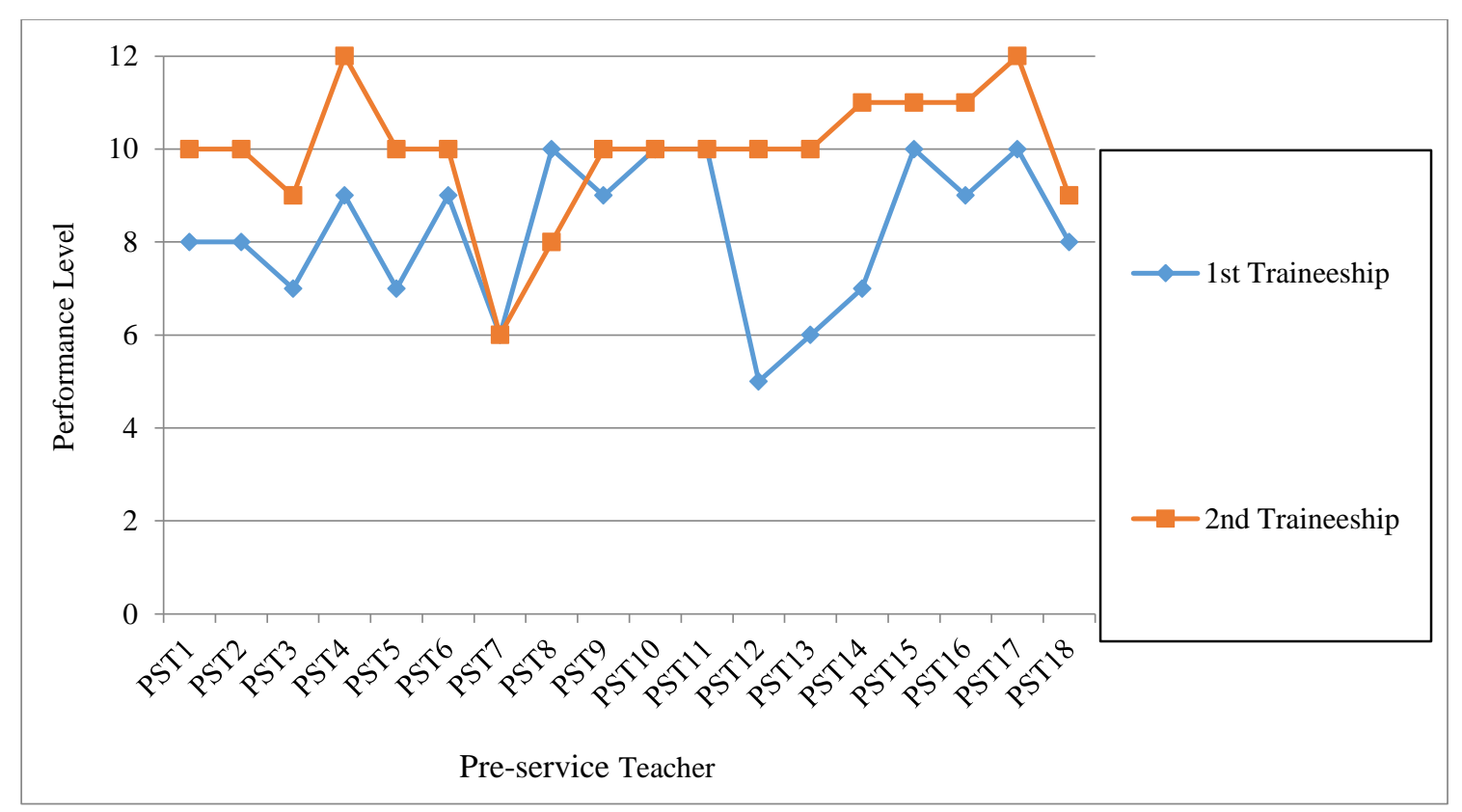

Figure 11. Rubric scores of the 1st traineeship process and the 2nd traineeship process

After these series of analysis were completed, we viewed lastly rubric scores of the 1st Traineeship Process and the 2nd Traineeship Process. Each PST's scores are shown in Figure 11 and analysis results are illustrated in Table 7. According to Table 7, statistically significant difference was found between PSTs' rubric scores of the 1 st Traineeship Process and the 2nd Traineeship Process performances $(z=3.01, p<.05)$. When mean rank and sum of ranks are taken in consideration, it is seen that the differences argue for positive ranks and this result is in favor of the 2nd Traineeship Process. In the light of analysis results, practicing through traineeship process can influence PSTs' skills been concerned with integrating digital games into classrooms.

Table 7. Analysis results of Wilcoxon Signed Rank Test towards Scores of the 1st traineeship process and the 2nd traineeship process

\begin{tabular}{llccccc}
\hline $\begin{array}{c}\text { Implementation } \\
\text { Pairs }\end{array}$ & & $\mathrm{N}$ & $\begin{array}{c}\text { Mean } \\
\text { Rank }\end{array}$ & $\begin{array}{c}\text { Sum of } \\
\text { Ranks }\end{array}$ & $\mathrm{Z}$ & $\mathrm{p}$ \\
\hline 1st Traineeship & Negative Ranks & 1 & 7.50 & 7.50 & $3.010^{*}$ & $.003^{* * *}$ \\
2nd Traineeship & $\begin{array}{l}\text { Positive Ranks } \\
\text { Ties }\end{array}$ & 14 & 8.04 & 112.50 & & \\
\hline *Based on negative ranks $\quad * * \mathrm{p}<.05$ & 3 & & & & \\
\end{tabular}

PST 12 who showed the highest increase in total rubric points developed a deep understanding about using Kodu and integrating it into curriculum. She listened actively to students and encouraged students to participate and discussion. She had a good grasp of whether or not the students understand the use of game and followed them with effective communication such as "Did I explain clearly?". PST 8 was the only participant who showed a decrease in total rubric points. Students were passive and didn't have enough time to grasp the information been introduced during her presentation. She didn't make any student assignment and didn't reach conclusions.

\section{Discussion and Conclusion}

The main purpose of this paper is to introduce Kodu Game Lab to pre-service science teachers through a method course based on MAGDAIRE framework and prepare them for designing their own digital games. In line with this purpose, a course plan based on MAGDAIRE was organized. Firstly, we made PSTs comprehend digital games integration into teaching processes and use of Kodu. Then, they started to design their own digital games in groups by using DGBL-ID Model.

In this paper, mixed method research design was used. TPKS-T been conducted to assess practically PSTs' skills about use of Kodu and rubrics aimed to evaluate levels of performances towards both groups' oral presentation and PSTs personal exercises in group works were used to collect quantitative data. Observation 
form consisted of ten main topics was used to collect qualitative data. Each implementation of all groups was evaluated separately and was given feedback to all groups about their performances. We evaluated data that was collected with TPKS-T to evaluate PSTs' skills about using Kodu. Analysis results of TPKS-T data showed that PSTs' post-test mean is significantly higher than their pre-test mean. According to this finding, it can be determined that PSTs' skills about designing digital game activities with Kodu can be developed by using MAGDAIRE cycle and working in groups.

When data been collected with rubrics termed as Rubric for Group Oral Presentation and Rubric for Student Exercise was investigated, it was seen that scores been gained from implementations of 2nd MAGDAIRE and 2nd Traineeship Process were respectively higher than total rubric scores of 1st MAGDAIRE and 1st Traineeship Process practices. According to analysis results, the differences between the rubric scores are statistically significant and the differences are in favors of implementations of the 2nd MAGDAIRE and the 2nd Traineeship Process. In light of these findings, it can be stated that rubric scores are directly proportionate to practices. As PSTs gain experiences, they start to transform into active users of digital games in classroom. Baek (2010) underlined that educators who are unfamiliar with digital games should learn about them and their contributions to education and this awareness is really important since educators can use digital games more easily in their classrooms, promoting learning can be actualized more effectively, and a factor oriented increasing motivation for students can be formed by means of it. We created a classroom environment where PSTs could get information about digital games and make practices with them. In this context, we think that one of the reasons about PSTs performance increase is experience. To identify the importance of experience, examination of barriers in technology integration into learning environment can be helpful. According to Ertmer (1999), experiencing is one of the barriers and PSTs should be given opportunities about using efficient technology tools throughout teacher education program in both content/method courses and field experiences (Ertmer and Ottenbreit-Leftwich 2010). Also, Bingimlas (2009) emphasized that PSTs should experience in self-organization and time management. In this paper, we observed that PSTs had problems about arranging course time and organization at the beginning of the process, but they overcame the problems in time.

Findings obtained from observation forms are consistent with aforementioned results. PSTs' performances such as classroom management, content and organization, pedagogical approaches made progress with implementations and their performance levels showed increases. In addition to experience, our observations showed that pedagogical beliefs have an effect on using digital games. Beliefs that feature in understanding teachers' behaviors (Kane, Sandretto and Heath 2002) are important factors of technology integration (Ertmer and Ottenbreit-Leftwich 2010). According to Hennessy, Ruthven and Brindley (2005), PSTs who use technology in their implementations move away from traditional beliefs effected negatively technology integration (Haney, Lumpe, Czerniak and Egan 2002) and they develop beliefs towards technology use. In our study, findings of pedagogical approaches and student response been topics of observation form showed that PSTs started to exhibit behaviors such as confident, organized, willing. According to Ertmer and OttenbreitLeftwich (2010), pedagogical beliefs can be changed by using current reflections and discussions. The mentioned change promotes our results.

In addition to all these, we can determine that knowledge and skills can be an important factor to integrate digital games into the classroom. Since courses involved subjects towards how digital games can be used and designed are quite few in curriculum of universities (Baek 2010; Becker 2007), teachers have absence of understanding about how digital games can be used (Becker 2007). This paper's results showed that PSTs' skills towards designing digital games were developed throughout the implementation processes as mentioned above. When PSTs started to use Kodu effectively, their activities were improved, and they presented well-organized activities wishfully in the classroom. This result is in accordance with the literature. Ertmer and OttenbreitLeftwich (2010) indicated that knowledge and skills are key concepts in technology integration and teachers need to feel sufficiently skilled about using technologies in their classrooms (Ashrafzadeh and Sayadian 2015). In light of these results, we can suggest that knowledge and skills, pedagogical beliefs and experience are important factors about integrating digital games into classroom environment.

\section{References}

Akçaoğlu, M. (2013). Cognitive and motivational impacts of learning game design on middle school children (Doctoral dissertation). Michigan State University, ABD.

Akçaoğlu, M., \& Koehler, M. J. (2014). Cognitive outcomes from the Game-Design and Learning (GDL) afterschool program. Computers \& Education, 75, 72-81. 
Alaswad, Z., \& Nadolny, L. (2015). Designing for Game-Based Learning: The effective integration of technology to support learning. Journal of Educational Technology Systems, 43(4), 389-402.

Amory, A., Naicker, K., Vincent, J., \& Adams, C. (1999). The use of computer games as an educational tool: identification of appropriate game types and game elements. British Journal of Educational Technology, 30(4), 311-321.

Ashrafzadeh, A., \& Sayadian, S. (2015). University instructors' concerns and perceptions of technology integration. Computers in Human Behavior, 49, 62-73.

Baek, Y. K. (Ed.). (2010). Gaming for classroom-based learning: Digital role playing as a motivator of study. Hershey: IGI Global.

Becker, K. (2007). Digital game- based learning once removed: Teaching teachers. British Journal of Educational Technology, 38(3), 478-488.

Bingimlas, K. A. (2009). Barriers to the successful integration of ICT in teaching and learning environments: A review of the literature. Eurasia Journal of Mathematics, Science \& Technology Education, 5(3), 235245.

Bruner, J. S. (1961). The act of discovery. Harvard Educational Review, 31(1), 21-32.

Chen, H., Wigand, R. T., \& Nilan, M. S. (1999). Optimal experience of web activities. Computers in Human Behavior, 15(5), 585-608.

Chien, Y. T., Chang, C. Y., Yeh, T. K., \& Chang, K. E. (2012). Engaging pre-service science teachers to act as active designers of technology integration: A MAGDAIRE framework. Teaching and Teacher Education, 28(4), 578-588.

Coffin, D. G. (2002). Saving time with a rubric buffet. Strategies, 16(1), 5-8.

Creswell, J. W. (2012). Educational research: Planning, conducting, and evaluating quantitative and qualitative research (4th ed.). Boston: Pearson Education.

Cohen, J. (1988). Statistical power analysis for the behavioral sciences (2nd ed.). Hillsdale, NJ: Erlbaum.

De Aguilera, M., \& Mendiz, A. (2003). Video games and education: (Education in the face of a "Parallel School"). Computers in Entertainment, 1(1), 1.

De Freitas, S. I. (2006). Using games and simulations for supporting learning. Learning, Media and Technology, 31(4), 343-58.

Ertmer, P. A. (1999). Addressing first-and second-order barriers to change: Strategies for technology integration. Educational Technology Research and Development, 47(4), 47-61.

Ertmer, P. A., \& Ottenbreit-Leftwich, A. T. (2010). Teacher technology change: How knowledge, confidence, beliefs, and culture intersect. Journal of Research on Technology in Education, 42(3), 255-284.

Feng, J., Spence, I., \& Pratt, J. (2007). Playing an action video game reduces gender differences in spatial cognition. Psychological Science, 18(10), 850-855.

Garris, R., Ahlers, R., \& Driskell, J. E. (2002). Games, motivation, and learning: A research and practice model. Simulation \& Gaming, 33(4), 441-467.

Gee, J. P. (2005). Learning by design: Good video games as learning machines. E-Learning and Digital Media, 2(1), 5-16.

Granic, I., Lobel, A., \& Engels, R. C. (2014). The benefits of playing video games. American Psychologist, 69(1), 66-78.

Gros, B. (2007). Digital games in education: The design of games-based learning environments. Journal of Research on Technology in Education, 40(1), 23-38.

Haney, J. J., Lumpe, A. T., Czerniak, C. M., \& Egan, V. (2002). From beliefs to actions: The beliefs and actions of teachers implementing change. Journal of Science Teacher Education, 13(3), 171-187.

Hennessy, S., Ruthven, K., \& Brindley, S. (2005). Teacher perspectives on integrating ICT into subject teaching: Commitment, constraints, caution, and change. Journal of Curriculum Studies, 37(2), 155-192.

Hew, K. F., \& Brush, T. (2007). Integrating technology into K-12 teaching and learning: Current knowledge gaps and recommendations for future research. Educational Technology Research and Development, 55(3), 223-252.

Ifenthaler, D., Eseryel, D., \& Ge, X. (Eds.). (2012). Assessment in game-based learning: Foundations, innovations and perspectives. New York: Springer.

Kane, R., Sandretto, S., \& Heath, C. (2002). Telling half the story: A critical review of research on the teaching beliefs and practices of university academics. Review of Educational Research, 72(2), 177-228.

Kirriemuir, J. (2002). The relevance of video games and gaming consoles to the higher and further education learning experience. Techwatch Report, 2, 15.

Koster, R. (2013). Theory of fun for game design (2nd ed.). O'Reilly Media, Inc.

Liu, E. Z. F., \& Chen, P. K. (2013). The effect of game-based learning on students' learning performance in science learning-A case of "conveyance go". Procedia-Social and Behavioral Sciences, 103, 1044-1051.

Luft, J. A. (1999). Rubrics: Design and use in science teacher education. Journal of Science Teacher Education, 10(2), 107-121. 
MacLaurin, M. B. (2011, January). The design of Kodu: A tiny visual programming language for children on the Xbox 360. In Proceedings of the 38th annual ACM SIGPLAN-SIGACT symposium on Principles of programming languages (pp. 241-246).

Mento, A. J., \& Giampetro-Meyer, A. (2000). Peer observation of teaching as a true developmental opportunity. College Teaching, 48(1), 28-31.

Mertler, C. A. (2001). Designing scoring rubrics for your classroom. Practical Assessment, Research \& Evaluation, 7(25), 1-10.

Microsoft Research, Kodu Project. (http://research.microsoft.com/en-us/projects/kodu).

Mitchell, A., \& Savill-Smith, C. (2004). The use of computer and video games for learning: A review of the literature. London: Learning and Skills Development Agency.

Montgomery, K. (2000). Classroom rubrics: Systematizing what teachers do naturally. The Clearing House, 73(6), 324-328.

Montgomery, K. (2002). Authentic tasks and rubrics: Going beyond traditional assessments in college teaching. College Teaching, 50(1), 34-40.

Natale, M. J. (2002). The effect of a male-oriented computer gaming culture on careers in the computer industry. ACM SIGCAS Computers and Society,32(2), 24-31.

Prensky, M. (2001). Digital game-based learning. New York: McGraw Hill.

Qian, M., \& Clark, K. R. (2016). Game-based learning and 21st century skills: A review of recent research. Computers in Human Behavior, 63, 50-58.

Ray, B., \& Coulter, G. A. (2010). Perceptions of the value of digital mini-games: Implications for middle school classrooms. Journal of Computing in Teacher Education, 26(3), 92-100.

Ritchie, D., \& Dodge, B. (1992, March). Integrating Technology Usage across the Curriculum through Educational Adventure Games. Paper presented at the meeting of Technology and Teacher Education Conference. Houston.

Shaffer, D. W., Halverson, R., Squire, K. R., \& Gee, J. P. (2005). Video Games and the Future of Learning. WCER Working Paper No. 2005-4. Wisconsin Center for Education Research (NJ1).

Shute, V. J., Rieber, L., \& Van Eck, R. (2011). Games... and... learning. Trends and Issues in Instructional Design and Technology, 3.

Sitzmann, T. (2011). A meta- analytic examination of the instructional effectiveness of computer- based simulation games. Personnel Psychology, 64(2), 489-528.

Spires, H. A. (2015). Digital game-based learning. Journal of Adolescent \& Adult Literacy, 59(2), 125-130.

Touretzky, D. S. (2014, December 5). Teaching Kodu with physical manipulatives. ACM Inroads, p. 44.

Uttal, D. H., Meadow, N. G., Tipton, E., Hand, L. L., Alden, A. R., Warren, C., \& Newcombe, N. S. (2013). The malleability of spatial skills: a meta-analysis of training studies. Psychological Bulletin, 139(2), 352.

Vogel, J. J., Vogel, D. S., Cannon-Bowers, J., Bowers, C. A., Muse, K., \& Wright, M. (2006). Computer gaming and interactive simulations for learning: A meta-analysis. Journal of Educational Computing Research, 34(3), 229-243.

Whitton, N. (2010). Learning with digital games. A practical guide to engaging students in higher education. Routledge, UK.

Zin, N. A. M., Yue, W. S., \& Jaafar, A. (2009). Digital game-based learning (DGBL) model and development methodology for teaching history. WSEAS Transactions on Computers, 8(2), 322-333.

\section{Author Information}

Gülşah Uluay

Ordu University

Education Faculty, Ordu, Turkey

Contact e-mail: gulsahuluay@gmail.com

\section{Alev Doğan}

Gazi University

Gazi Education Faculty, Ankara, Turkey 